\title{
An index of forest management intensity based on assessment of harvested tree volume, tree species composition and dead wood origin
}

\author{
Tiemo Kahl', Jürgen Bauhus' \\ I Chair of Silviculture, Faculty of Environment and Natural Resources, University of Freiburg, Germany \\ Corresponding author: Tiemo Kahl (tiemo.kahl@waldbau.uni-freiburg.de)
}

Academic editor: K. Henle | Received 17 February 2014 | Accepted 17 March 2014 | Published 9 April 2014

Citation: Kahl T, Bauhus J (2014) An index of forest management intensity based on assessment of harvested tree volume, tree species composition and dead wood origin. Nature Conservation 7: 15-27. doi: 10.3897/natureconservation.7.7281

\begin{abstract}
Forest management intensity often affects biodiversity, ecosystem processes and ecosystem services. To assess the influence of past management intensity on current ecosystem properties, management intensity must be quantified in a meaningful and reproducible approach. Here we developed the simple yet effective Forest Management Intensity index (ForMI), which is based only on inventory data of the living stand, stumps and dead wood. The ForMI is the sum of three components taking into account: 1 . the proportion of harvested tree volume (Iharv), 2. the proportion of tree species that are not part of the natural forest community (Inonat) and 3. the proportion of dead wood showing signs of saw cuts (Idwcut). Each component ranges between 0 (no sign of management) and 1 (intensive management). Our analysis suggests that the ForMI can be used to assess management intensity in Central European forests for the last 30 to 40 years, depending on decay rates of stumps and dead wood. Our approach was tested using data of 148 forest plots of 1 ha in size in Germany. We found a significant distinction between plots that were previously described as managed and unmanaged as well as between plots comprising trees species of the natural forest community and those with additional, introduced coniferous tree species. We conclude that the index is applicable to a wide range of forest management types, but should not be misinterpreted as an index for old-growth structure.
\end{abstract}

\section{Keywords}

Land-use intensity, Biodiversity exploratories

Copyright Tiemo Kahl, Jürgen Bauhus. This is an open access article distributed under the terms of the Creative Commons Attribution License (CC BY 4.0), which permits unrestricted use, distribution, and reproduction in any medium, provided the original author and source are credited. 


\section{Introduction}

Forest management intensity is suggested to be a main driver of biodiversity, ecosystem processes and ecosystem services (Fischer et al. 2010, Gustafsson et al. 2012). To assess the influence of past management intensity on current ecosystem properties, management intensity must be quantified in a meaningful and reproducible approach. Here we are concentrating on influences of silvicultural forest management at the stand level, which represents impacts at the ecosystem level. So far, there is no straightforward and agreed approach for its quantification. The main challenge in developing such an index of forest management intensity is to incorporate the different elements of forest management that affect stand structure and composition and to quantify these. Recently, approaches have been suggested that require theoretically derived variables, which are not directly related to a particular forest stand in question (Luyssaert et al. 2011, Schall and Ammer 2013). Schall and Ammer (2013) provided an extensive review on concepts and approaches for assessing land-use and specifically forest management intensity to provide the scientific basis for their approach. We believe that the two previous approaches produced indicators of forest management intensity that are not entirely transparent, not easy to quantify, and not strictly or exclusively related to human pressure on forest ecosystems; see Niemeijer and de Groot (2008) for a discussion of properties of useful environmental indicators. Here we propose an alternative approach, the index of Forest Management Intensity (ForMI), which is derived from stand inventory data of living trees, stumps and dead wood. The ForMI is the sum of three components taking into account: 1. the proportion of harvested tree volume (Iharv), 2. the proportion of tree species that are not part of the natural forest composition (Inonat) and 3. the proportion of dead wood showing signs of saw cuts (Idwcut). In the following we provide the rational for constructing the index from these three components.

One core activity of forest management consists of the harvest of living trees. There are a variety of silvicultural approaches leading to even-aged forest stands characterized by distinct age-classes or uneven-aged forest stands resulting from selection cutting. Despite the large differences between those silvicultural approaches the result is always the removal of wood. Unfortunately, the records about the amount of wood volume removed are often not specific at the stand level but are documented for compartments or management units, and not all assortments may be traced; e.g. firewood may not be recorded. However, tree removals are traceable by tree stumps left after cutting. To gain a relative measure of the amount of harvested tree volume, the difference between the observed standing volume to the maximum volume based on the self-thinning relationship for a particular age and tree species (Spellmann et al. 1999) may be used (Luyssaert et al. 2011, Schall and Ammer 2013). One major drawback of this approach is the reliance on a theoretical maximum stand carrying capacity, which is influenced by site conditions and tree species. Since these relationships are mainly established for mono-specific and even-aged stands, mixed and uneven-aged stands are rather poorly described (Pretzsch 2009). In addition, these approaches neglect disturbances, which may have affected a particular stand and influenced the difference between a potential 
and the actual wood volume. The indices of Schall and Ammer (2013) and Luyssaert et al. (2011) are therefore not a direct measure of the harvesting intensity for a particular forest stand and they do not distinguish between human pressure and natural reductions in standing tree volume. Thus we propose to quantify the proportion of wood that has been removed over a period of time that is still indicated by the stumps. This is a direct expression of human pressure, as is often used in environmental indicator sets (Niemeijer and de Groot 2008), on the particular forest ecosystem in question.

In addition to harvesting, the composition of tree species is one of the main factors influenced by forest management. Although preindustrial forest management and land use change may have altered the natural tree species composition already, there is no doubt that the shift in tree species composition following the early industrial period towards secondary forests comprising coniferous species (Picea abies, Pinus sylvestris) in Central Europe has had a profound influence on forest ecosystems (Bohn et al. 2004, Ellenberg and Leuschner 2010). This element of the index therefore considers the influence on ecosystem properties and processes triggered by human-induced changes of tree species composition. Introduced tree species may change the habitat for herbivores and their predators (e.g. Gossner and Ammer 2006), the disturbance dynamics because they are more susceptible to certain disturbance factors (e.g. Albrecht et al. 2012), or ecosystem nutrient cycling and soil properties (e.g. Binkley and Giardina 1998) to name a few of such alterations. Here we refer to "natural" or "non-natural" tree species as those, which are, or are not, part of the potential natural vegetation (Tüxen 1956) that would occur as an expression of soil and climate at the observed site

Since in actively managed forests, wood is regularly removed, both the quantity and quality of dead wood are substantially altered when compared to unmanaged forests (Jonsson et al. 2005). At the same time, dead wood is of critical importance for many ecosystem functions (Harmon et al. 1986), of which the most relevant are C sequestration (e.g. Litton et al. 2007, Kahl et al. 2012), nutrient cycling (Brunner and Kimmins 2003, Kuehne et al. 2008), and provision of habitat for wood-dwelling organisms (Lonsdale et al. 2008, Rondeux and Sanchez 2010). For example, in Germany, 56\% of all forest Coleoptera are dependent on dead wood (Köhler 2000). Consequently, the amount of standing and lying dead wood has been adopted as one of the Pan-European Indicators of sustainable forest management (MCPFE 2002). However, since the quantity of dead wood is highly variable in managed as well as in unmanaged forests of Central Europe (own data), it is unlikely to be a good indicator for forest management intensity. While in long-term unmanaged forests, large quantities of dead wood will accumulate (Christensen et al. 2005), this may not occur in the short-term, in particular when harvesting ceases at a time of stand development, when little dead wood is created through processes, such as self-thinning or disturbances (Harmon 2009). For example, an intensive harvesting operation may leave large quantities of dead wood if the utilization standards are low. Taking this into account, and in order to keep dead wood quantity as an independent variable for further statistical analysis, we selected a variable that is largely independent of dead wood quantity but describes its quality by means of its origin. Forest management generally tries to avoid 
the natural death of trees since this would reduce the quality of the products or the amount of harvestable wood volume. This in turn leads to a decrease of dead wood originating from natural mortality of trees. At the same time in managed forests, more dead wood originates from the cutting of trees and therefore shows saw cuts. Hence we used the proportion of dead wood with signs of saw cuts as the third component of the proposed index.

In the following, we present the definition of the proposed ForMI and show an application to a set of 148 forest plots as well as a comparison with two other indices that have been calculated for the same plots.

\section{Methods}

\section{Definition of ForMI}

The first component of the index Iharv describes the proportion of harvested tree volume. Our approach is based on the assumption that the sum of the living standing tree biomass (1), harvested tree biomass removed from the stand (including the logging waste in the stand) (2), and the dead wood biomass of trees that died naturally (no chain saw cuts) (3) can be used as a proxy for the potential cumulative merchantable volume (Pretzsch 2005) at a given stand age. This approach makes the assumption of a theoretical maximum stand carrying capacity redundant and is independent of site quality, previous disturbances and tree species composition. Cut stumps are used to derive estimates of the harvested volume.

The main drawback of this approach is the uncertainty about the time until the stumps and dead wood are decayed. The decay rate of stumps depends mainly on tree species, site conditions and size (Shorohova et al. 2012). For southern Finland stump turn-over times of 61, 56 and 43 years for pine (Pinus sylvestris), spruce (Picea abies) and birch (Betula spec.), respectively, were found (Shorohova et al. 2012). In the case of European beech (Fagus sylvatica), which is the dominant deciduous tree species in Central Europe, we assume that the stump turnover time is similar to the turnover time of logs, about 54 years (Kahl et al. 2012). These values should be considered as maxima for the longevity of stumps and a time of 30 to 40 years seems realistic for the probability to find remains of cut stumps. Cut stumps of Central European tree species, such as oak (Quercus spec.), which are known to be more decay resistant, would add a bias to this stump-based approach. Stump size (diameter) seems to have only little influence on stump turnover time. No influence of size on stump turnover time was found for Picea abies in Sweden (Melin et al. 2009). The same was true for stumps of Picea abies and Pinus sylvestris in a study in Finland, while the turnover time of Betulus spec. stumps in the same study slightly increased with size (Shorohova et al. 2012). In addition, contradictory results have been reported for the influence of diameter on the decay rate of wood. For example, decay rates for dead wood of Picea abies increased (Næsset 1999) or decreased with increasing diameter (Brown et al. 1996). Regarding these studies we 
believe that stump size is far less important for stump turnover time than may be assumed. Since stump turnover time is the most critical point in this context, we suggest restricting this approach to regional scale comparisons of forest management intensity to minimize the influence of climate on decomposition rates of stumps.

Although stump turnover time maybe highly variable, this approach has the advantage that the influence of tree harvest recognisable as stumps virtually decays with time. Harvesting events that occurred recently can be fully considered, whereas harvesting events that date further back will have increasingly less influence on this measure, which presumably also reflects a decreasing legacy influence. The harvested tree volume determined in this way is certainly less accurate than could be derived from repeated inventory or detailed, stand-based harvesting records, however, in most cases these do not exist. So the sum of harvested volume, dead wood volume and the living volume provides the proxy for the potential cumulative merchantable volume of the last 30-40 years.

The Iharv is calculated as the ratio of harvested volume to the sum of standing, harvested and dead wood volume. A value of 1 represents a clear-cut site, where tree regeneration has not yet reached the minimum tree diameter limit used for inventory purpose and no dead wood occurs, and a ratio of 0 means that no tree harvest occurred within the last 30-40 years. The index Iharv can only be applied, where conventional forest management using chain saws or a harvester leaves stumps. In general it can be said that all parameters (e.g. tree species, size, climate) that increase stump turnover time will also increase the component Iharv.

The component Inonat is a measure for the volume proportion of non-natural tree species. It is estimated as the proportion of harvested, living and dead wood (without saw cuts) volume of non-natural tree species to the sum of harvested, living and dead wood (without saw cuts) volume of all tree species. Again here, the legacy of former stand conditions (e.g. a cohort of introduced spruce trees that were harvested within a time frame of 30-40 years prior to assessment of forest management intensity in a forest composed now entirely of tree species belonging to the natural forest vegetation) is taken into account. A value of 1 means that the whole stand consists of non-natural tree species, whereas a value of 0 is a stand composed of tree species belonging to the natural forest vegetation only.

The component Idwcut represents the proportion of dead wood volume with saw cuts to the total amount of dead wood volume. A value of 1 means that all dead wood originated from management activity (wood residue) or that trees that died by natural causes were cut and used, while a value of 0 means that all dead wood is a result of natural tree death. In case where no dead wood occurs but clear signs of management are visible e.g. due to fuel sampling or in plantation forests with whole tree harvesting we recommend to adjust the Idwcut to a value of 1 .

The forest management index ForMI is the sum of all three components Iharv, Inonat and Idwcut. Although the relative importance of each component as an indicator of forest management intensity is debatable, we decided to weigh each component by a value of 1 . For example, a ForMI of 3 would apply to a clear-cut stand of non-natural 
tree species, where no dead wood of natural origin occurs. A value of 0 would apply to a stand, where no stumps were found, only natural tree species and only dead wood without saw cuts occur. The ForMI describes strictly past management intensity and does not aim to describe forest structure or level of oldgrowthness (c.f. Bauhus et al. 2009). This is due to the fact that stand age and absolute stand volume do not play a role. A value of 0 could equally apply to a 20 -years-old stand in an early successional stage after a stand-replacing fire or as primary successional vegetation on a river bank, but it also could represent a 500-years-old primeval forest.

\section{Application of ForMI}

To test our approach, we used inventory data of the 150 forest experimental plots of the German Biodiversity Exploratories (Fischer et al. 2010). The 1 ha $(100 \mathrm{~m} \times 100$ $\mathrm{m})$ sized plots are equally distributed in three exploratories representing the regions: Schwäbische Alb (Alb), Hainich-Dün (H-D) and Schorfheide-Chorin (S-C). The predominant silvicultural systems and forest management types in each region were considered. These produce even-aged coniferous stands (Picea abies, Pinus sylvestris), even-aged beech (Fagus sylvatica) stands, uneven-aged beech stands, and even-aged oak (Quercus spec.) stands. In addition, there are extensively managed or unmanaged beech-dominated forests. The even-age stands are later referred to as age-class forest. The inventory data of the living stands are based on a plot inventory $\left(500 \mathrm{~m}^{2}\right)$ carried out in 2008 and 2009 (Fischer et al. 2010, Hessenmöller et al. 2011). Dead wood inventories were conducted in 2012 using a stratified sampling design with all standing and downed dead wood $>25$ $\mathrm{cm}$ being recorded on the 1 ha plot (volume calculations based on Meyer 1999) and downed dead wood $>7 \mathrm{~cm}$ and $<25 \mathrm{~cm}$ being estimated using the line intersect method (Warren and Olsen 1964, Van Wagner 1982) with two perpendicular transects of together $270 \mathrm{~m}$ length. Information on saw cuts and dead wood volume was then used to calculate the Idwcut. Stumps $>7 \mathrm{~cm}$ diameter were estimated on $2 \mathrm{~m}$ wide strips along the same transects, which served as central line of the strips. The area covered by these strip-transects was $522 \mathrm{~m}^{2}$. Volume of harvested trees was calculated based on allometric functions (Muukonen 2007). Data of 148 plots were available for this analysis. The new index ForMI was compared with the existing land use and disturbance intensity (LUDI) approach by Luyssaert et al. (2011) on all available 148 plots and with the Silvicultural Management Index (SMI) by Schall and Ammer (2013) on a subset of 30 plots. All analyses were performed in R 3.0.2 (www.r-project.org).

\section{Results and discussion}

The ForMI provided a clear distinction between managed and unmanaged forests (Wilcox Test $\mathrm{p}<0.001$ ) (Fig. 1). The main difference between managed and unmanaged forests was caused by the low number of stumps and the low amount of dead wood 


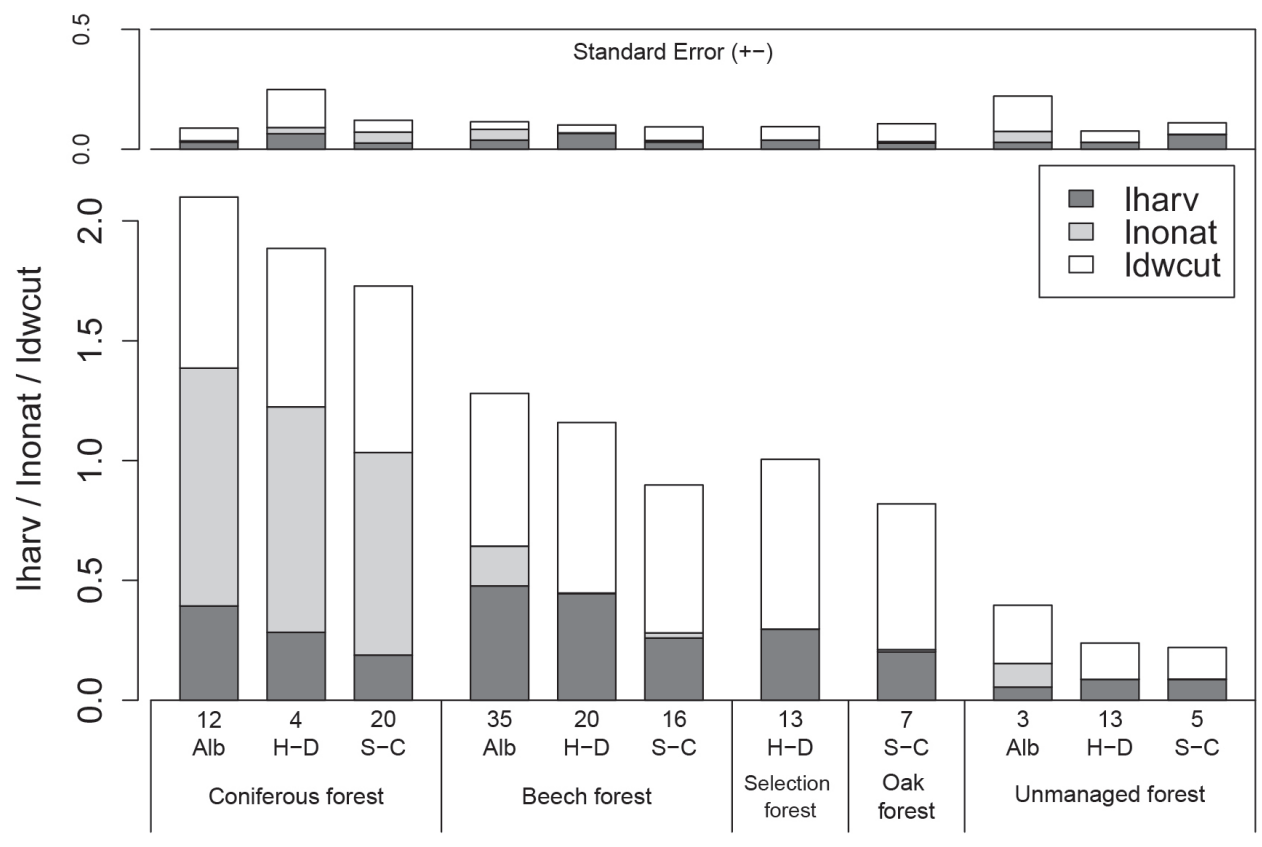

Figure I. Distribution of the forest management intensity index ForMI and its 3 components across 5 different forest management types in the Biodiversity exploratories Schwäbische Alb (Alb), Hainich-Dün (H-D) and Schorfheide-Chorin (S-C). Numbers below the bars indicate the number of plots per group. The second bar plot above shows the standard error for each component. In the exploratories Alb and H-D, coniferous forest comprises even-aged Picea abies stands, and in the S-C exploratory Pinus sylvestris age class forest. Beech forest in all exploratories refers to even-aged Fagus sylvatica stands. Selection forest in the H-D exploratory is uneven-aged selection cutting stands dominated by Fagus sylvatica. Oak forest in the S-C exploratory is even-aged Quercus spec. forest. Unmanaged forest in the Alb exploratory represents extensively managed Fagus sylvatica forest, in the H-D and S-C it has been unmanaged for 10-60 years.

with saw cuts in unmanaged forests. Four out of 21 unmanaged stands had a ForMI of 0 , which suggests that they have been unmanaged for at least 30-40 years. This result is congruent with other information about these unmanaged forest plots (Fischer et al. 2010). The largest contribution to the high ForMI value of coniferous forests was attributable to the Inonat component, which is close to 1 in mono-specific coniferous forests. The three variables of the ForMI presented here were calculated based on the volume of living, harvested and dead trees. For the calculation of Iharv and Inonat also the use of basal area was tested for 29 selected plots. Because basal area of dead wood could not be estimated, Iharv was calculated based on harvested and standing tree volume only. A comparison based on a linear model between the ForMI based on volume calculations as predictor variable and the basal area approach as predicted variable shows that both yield comparable result $\left(a=0.97, b=0.13, p<0.001, R^{2}=0.97\right)$.

The ForMI as well as its three components cover the whole range of values across the 148 experimental plots (Fig. 2). The distribution of Iharv is right-skewed indicat- 

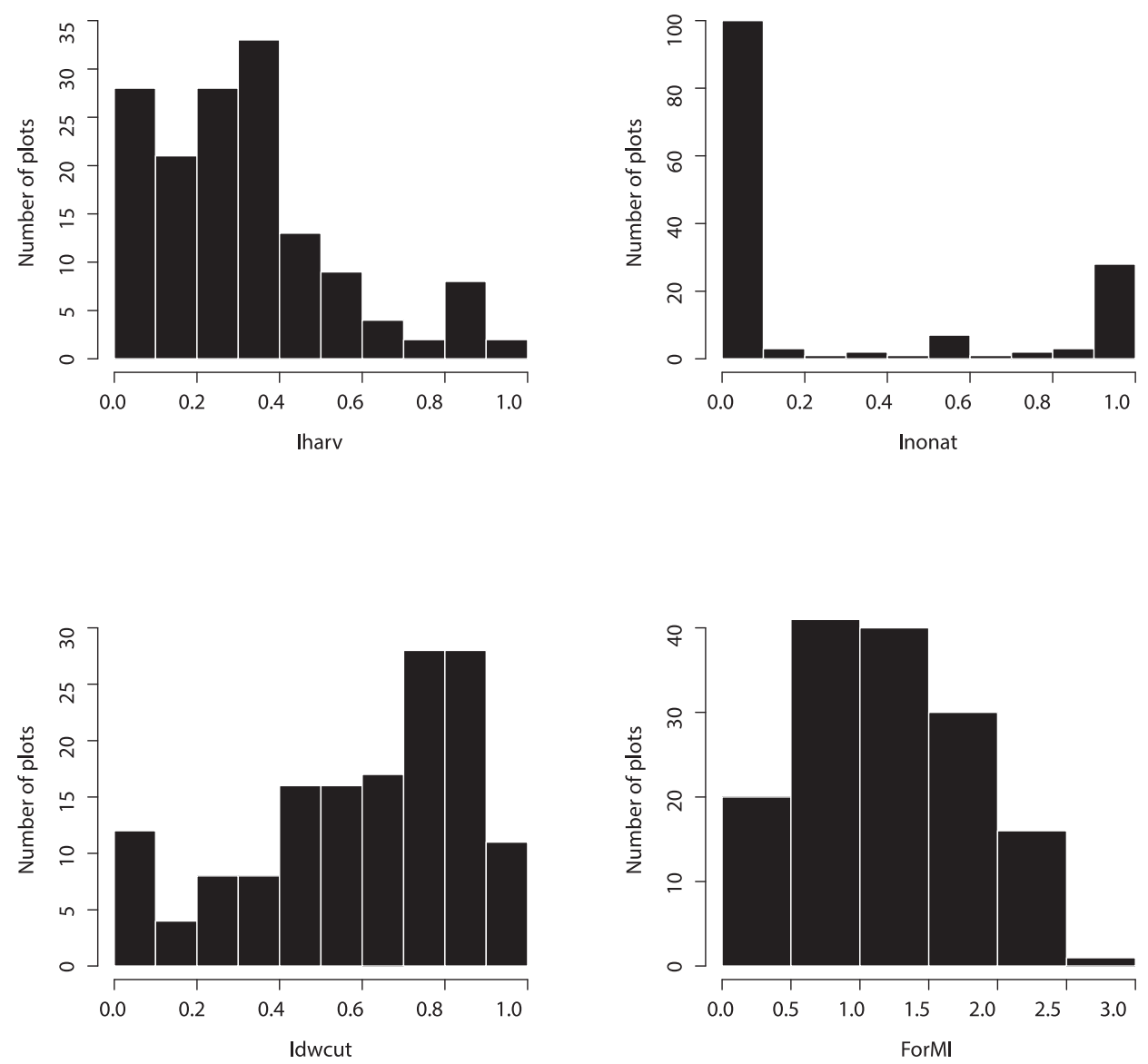

Figure 2. Distribution of the forest management intensity components: Iharv - proportion of harvested volume; Inonat - proportion of non-natural tree species; Idwcut - proportion of dead wood volume with saw cuts; and of the combined ForMI - forest management intensity index. Total number of forest plots is 148 .

ing that only few plots experienced rather intensive recent harvest. The distribution of Inonat shows a bimodal shape with two maxima, one at 0 (only natural tree species), reflecting the dominance of beech plots among the exploratories, and one at 1 (only non-natural tree species) and only few stands, where these two tree species groups occur together. Idwcut shows a left-skewed distribution indicating that in most stands dead wood has been created by harvesting activities. The distribution of ForMI is slightly right-skewed and peaks at a value of 1 . No relationship between Iharv and Inonat was found while there were significant positive, but not strong relationships between Idwcut and Iharv and between Idwcut and Inonat (Fig. 3)

Schall and Ammer (2013) proposed the Silvicultural Management Index (SMI), which is composed of a tree species-specific risk and a density component. In their rationale, tree species selection affects among other things the susceptibility of forest 

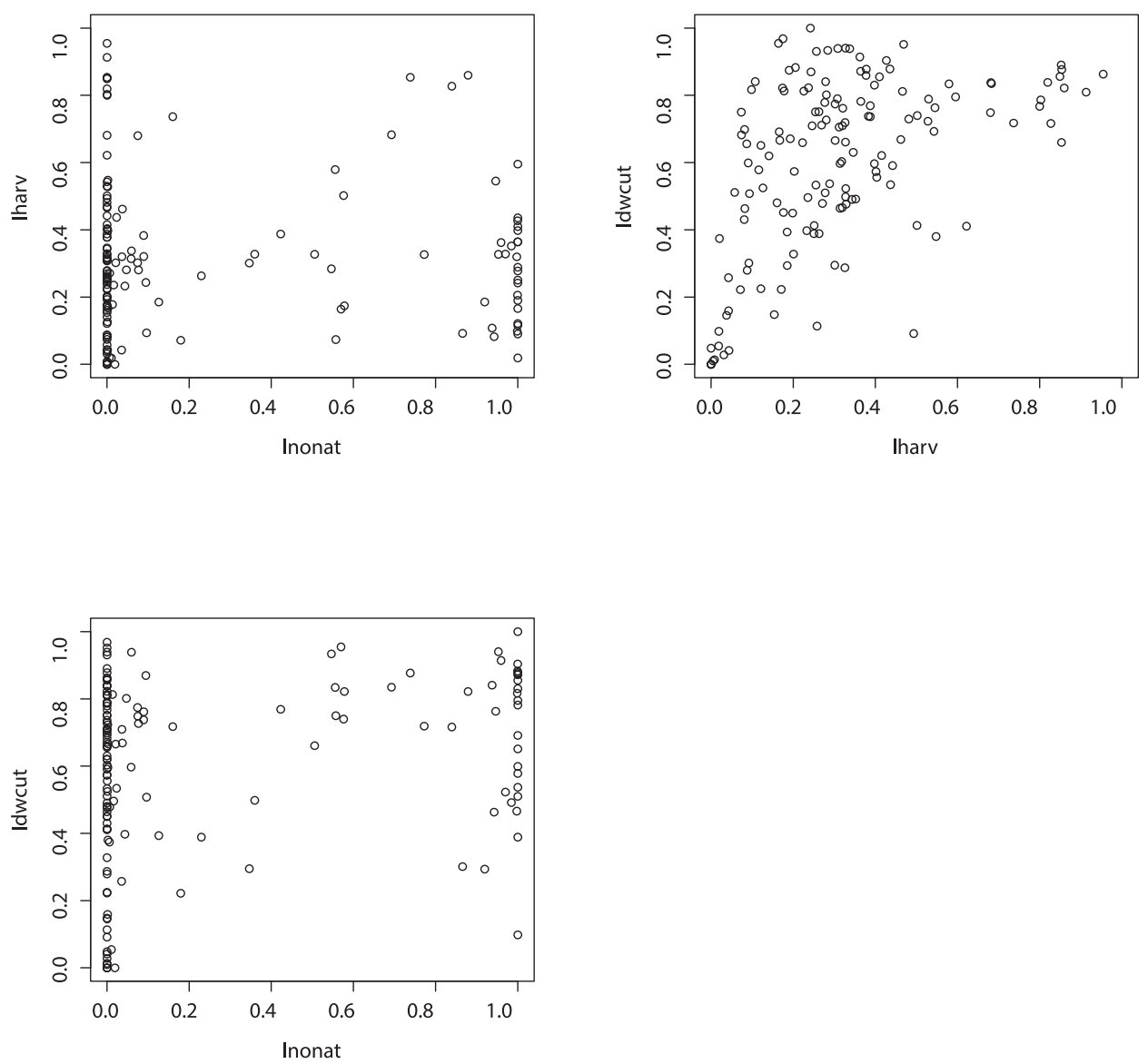

Figure 3. Relationships between the three components of the forest management intensity: Iharv, Inonat and Idwcut. Spearman rank correlation between Iharv-Inonat $\left(\mathrm{p}=0.64, \mathrm{r}_{\mathrm{s}}=0.04\right)$, Idwcut-Iharv $(\mathrm{p}<0.001$, $\left.\mathrm{r}_{\mathrm{s}}=0.5\right)$ and Idwcut-Inonat $\left(\mathrm{p}=0.01, \mathrm{r}_{\mathrm{s}}=0.21\right)$

stands to natural disturbances. With increasing susceptibility, management intensity, e.g. through thinning or harvesting, must be more frequent to reduce the risk of stand loss. In Central Europe the susceptibility to disturbance tends to be higher for secondary coniferous than for natural hardwood forests. Consequently, the risk component of Schall and Ammer (2013) is to some extent comparable to the Inonat, and their density component to the Iharv. The SMI approach was applied to a subset of 30 plots of the Biodiversity exploratories. A comparison based on a linear model between the SMI and the ForMI shows that both indices yield comparable results $\left(\mathrm{p}<0.001, \mathrm{R}^{2}=0.72\right)$. A comparison of the ForMI with the land use and disturbance intensity (LUDI) approach by Luyssaert et al. (2011), which is based on the same 148 plots used by us, showed that these indices do not converge and obviously capture different attributes of forests. The LUDI is based on the difference between the potential and the actual biomass storage and does not consider the intensification of forest management that 
is expressed by the change in tree species composition. Across all forest management types there was only a low although significant linear correlation $\left(\mathrm{p}<0.001, \mathrm{R}^{2}=0.07\right)$. For plots dominated by non-natural coniferous tree species (Picea abies, Pinus sylvestris, $\mathrm{n}=36)$, no significant correlation was found $(\mathrm{p}=0.28)$ while those plots dominated by hardwood species, such as Fagus sylvatica and Quercus sp. $(\mathrm{n}=112)$, had a significant correlation $\left(\mathrm{p}<0.001, \mathrm{R}^{2}=0.41\right)$.

The advantage of the ForMi is its simple yet effective approach, which allows the calculation based only on volume or basal area inventory data of the living stand, stumps, and dead wood. No additional assumptions and models with regard to maximum stand carrying capacity or risk potential have to be employed. The ForMI approach proved to be applicable to all observed silvicultural management systems and allows their direct comparison. Although we have not examined yet how different silvicultural management systems, such as clear-cutting or coppice with standards, or large-scale disturbances, such as storm damage or fire, may affect ForMI, we believe that this index is applicable across the whole range of forest management types, except when trees are harvested including their root stock. The disadvantage of the ForMI is that the assessment of harvesting intensity depends on the visibility and longevity of stumps, and that it does not take into account the management frequency and is therefore not useful to describe situations where management occurs in long time intervals that exceed the longevity of stumps, as may be the case in tropical lowland rainforests.

\section{Acknowledgement}

We thank the managers of the three exploratories, Swen Renner, Sonja Gockel, Kerstin Wiesner, and Martin Gorke for their work in maintaining the plot and project infrastructure; Simone Pfeiffer and Christiane Fischer giving support through the central office, Michael Owonibi for managing the central data base, and Markus Fischer, Eduard Linsenmair, Dominik Hessenmöller, Jens Nieschulze, Daniel Prati, Ingo Schöning, François Buscot, Ernst-Detlef Schulze, Wolfgang W. Weisser and the late Elisabeth Kalko for their role in setting up the Biodiversity Exploratories project. The work has been funded by the DFG Priority Program 1374 „Infrastructure-Biodiversity-Exploratories“ (BA 2821/9-2). Field work permits were issued by the responsible state environmental offices of Baden-Württemberg, Thüringen, and Brandenburg (according to $\$ 72$ BbgNatSchG). We thank Peter Mühlhäuser, Sandor Haller and Martin Nitsche for conducting the dead wood inventory and Peter Schall and one anonymous reviewer from Peerage of Science for their critical and helpful comments on a previous version of the manuscript.

\section{References}

Albrecht AT, Hanewinkel M, Bauhus J, Kohnle U (2012) How does silviculture affect storm damage in forests of south-western Germany? Results from empirical modeling based on 
long-term observations. European Journal of Forest Research 131: 229-247. doi: 10.1007/ s10342-010-0432-x

Bauhus J, Puettmann K, Messier C (2009) Silviculture for old-growth attributes. Forest Ecology and Management 258: 525-537. doi: 10.1016/j.foreco.2009.01.053

Binkley D, Giardina C (1998) Why do tree species affect soils? The warp and woof of tree-soil interactions. Biogeochemistry 42: 89-106. doi: 10.1023/A:1005948126251

Bohn U, Neuhäusl R, Gollub G, Hettwer C, Neuhäuslová Z, Raus T, Schlüter H, Weber H, (2004) Map of the Natural Vegetation of Europe, Scale 1:2500000. (Münster).

Brown S, Mo J, McPherson JK, Bell DT (1996) Decomposition of woody debris in Western Australian forests. Canadian Journal of Forest Research 26(6): 954-966. doi: 10.1139/ x26-105

Brunner A, Kimmins JP (2003) Nitrogen fixation in coarse woody debris of Thuja plicata and Tsuga heterophylla forests on northern Vancouver island. Canadian Journal of Forest Research 33: 1670-1682. doi: 10.1139/x03-085

Christensen M, Hahn K, Mountford EP, Odor P, Standovar T, Rozenbergar D, Diaci J, Wijdeven S, Meyer P, Winter S, Vrska T (2005) Dead wood in European beech (Fagus sylvatica) forest reserves. Forest Ecology and Management 210: 267-282. doi: 10.1016/j. foreco.2005.02.032

Ellenberg H, Leuschner C (2010) Vegetation Mitteleuropas mit den Alpen; In ökologischer, dynamischer und historischer Sicht. (Stuttgart).

Fischer M, Bossdorf O, Gockel S, Hänsel F, Hemp A, Hessenmöller D, Korte G, Nieschulze J, Pfeiffer S, Prati D, Renner S, Schöning I, Schumacher U, Wells K, Buscot F, Kalko EKV, Linsenmair KE, Schulze ED, Weisser WW (2010) Implementing large-scale and longterm functional biodiversity research: The Biodiversity Exploratories. Basic and Applied Ecology 11(6): 473-485. doi: 10.1016/j.baae.2010.07.009

Gossner M, Ammer U (2006) The effects of Douglas-fir on tree-specific arthropod communities in mixed species stands with European beech and Norway spruce. European Journal of Forest Research 125: 221-235. doi: 10.1007/s10342-006-0113-y

Gustafsson L, Baker SC, Bauhus J, Beese WJ, Brodie A, Kouki J, Lindenmayer DB, Lóhmus A, Martínez Pastur G, Messier C, Neyland M, Palik B, Sverdrup-Thygeson A, Volney WJA, Wayne A, Franklin JF (2012) Retention forestry to maintain multifunctional forests: a world perspective. Bioscience 62: 633-645. doi: 10.1525/bio.2012.62.7.6

Harmon ME, Franklin JF, Swanson FJ, Sollins P, Gregory SV, Lattin JD, Anderson NH, Cline SP, Aumen NG, Sedell JR, Lienkaemper GW, Cromack K, Cummins KW (1986) Ecology of Coarse Woody Debris in Temperate Ecosystems. Advances in Ecological Research 15: 133-302. doi: 10.1016/S0065-2504(08)60121-X

Harmon M (2009) Woody Detritus Mass and its Contribution to Carbon Dynamics of OldGrowth Forests: the Temporal Context. In: Wirth C, Gleixner G, Heimann M (Eds) Old-growth forests: Function, fate and value. Ecological Studies 207 (Berlin Heidelberg): 159-190. doi: 10.1007/978-3-540-92706-8_8

Hessenmöller D, Nieschulze J, von Lüpke N, Schulze ED (2011) Identification of forest management types from ground-based and remotely sensed variables and the effects of forest management on forest structure and composition. Forstarchiv 82: 171-183. 
Jonsson BG, Kruys N, Ranius T (2005) Ecology of species living on dead wood-lessons for dead wood management. Silva Fennica 39(2): 289-309.

Kahl T, Mund M, Bauhus J, Schulze ED (2012) Dissolved organic carbon from European beech coarse woody debris - patterns of input to and retention by surface soil. Ecoscience 19(4): 1-10. doi: 10.2980/19-4-3501

Köhler F (2000) Saproxylic beetles in nature forests of the northern Rhineland. Comparative studies on the saproxylic beetles of Germany and contributions to German nature forest research. Schrr LÖBF/LAfAO NRW 18 (Recklinghausen), 1-351.

Kuehne C, Donath C, Müller-Using SI, Bartsch N (2008) Nutrient fluxes via leaching from coarse woody debris in a Fagus sylvatica forest in the Solling Mountains, Germany. Canadian Journal of Forest Research 38: 2405-2413. doi: 10.1139/X08-088

Litton CM, Raich JW, Ryan MG (2007) Carbon allocation in forest ecosystems. Global Change Biology 13: 2089-2109. doi: 10.1111/j.1365-2486.2007.01420.x

Lonsdale D, Pautasso M, Holdenrieder O (2008) Wood-decaying fungi in the forest: conservation needs and management options. European Journal of Forest Research 127: 1-22. doi: 10.1007/s10342-007-0182-6

Luyssaert S, Hessenmöller D, von Lüpke N, Kaiser S, Schulze ED (2011) Quantifying land use and disturbance intensity in forestry, based on the self-thinning relationship. Ecological Applications 21(8): 3272-3284. doi: 10.1890/10-2395.1

Melin Y, Petersson H, Nordfjell T (2009) Decomposition of stump and root systems of Norway spruce in Sweden-A modelling approach. Forest Ecology and Management 257(5): 1445-1451. doi: 10.1890/10-2395.1

Meyer P (1999) Totholzuntersuchungen in nordwestdeutschen Naturwäldern: Methodik und erste Ergebnisse. Forstwissenschaftliches Centralblatt 118: 167-180. doi: 10.1007/ BF02768985

MCPFE: Ministerial Conference on the Protection of Forests in Europe, 2002, Improved PanEuropean indicators of sustainable forest management. http:/www.foresteurope.org/docs/ reporting/Vienna_Improved_Indicators.pdf

Muukkonen P (2007) Generalized allometric volume and biomass equations for some tree species in Europe. European Journal of Forest Research 126(2): 157-166. doi: 10.1007/ s10342-007-0168-4

Næsset E (1999) Decomposition rate constants of Picea abies logs in southeastern Norway. Canadian Journal of Forest Research 29(3): 372-381. doi: 10.1139/x99-005

Niemeijer D, de Groot RS (2008) A conceptual framework for slecting environmental indicator sets. Ecological Indicators 8: 14-25. doi: 10.1016/j.ecolind.2006.11.012

Pretzsch H (2005) Stand density and growth of Norway spruce (Picea abies (L.) Karst.) and European beech (Fagus sylvatica L.): evidence from long-term experimental plots. European Journal of Forest Research 124(3): 193-205. doi: 10.1007/s10342-005-0068-4

Pretzsch H (2009) Forest dynamics, growth and yield - from measurement to model. Springer, New York.

Rondeux J, Sanchez C (2010) Review of indicators and field methods for monitoring biodiversity within national forest inventories. Core variable: Deadwood. Environmental Monitoring Assessment 164: 617-630. doi: 10.1007/s10661-009-0917-6 
Schall P, Ammer C (2013) How to quantify forest management intensity in Central European forests. European Journal of Forest Research 132(2): 379-396. doi: 10.1007/s10342-0130681-6

Shorohova E, Ignatyeva O, Kapitsa O, Kauhanen H, Kuznetsov A, Vanha-Majamaa I (2012) Stump decomposition rates after clear-felling with and without prescribed burning in southern and northern boreal forests in Finland. Forest Ecology and Management 263: 74-84. doi: 10.1016/j.foreco.2011.09.006

Spellmann H, Nagel J, Böckmann T (1999) Summarische Nutzungsplanung auf der Basis von Betriebsinventuren. Allgemeine Forst- und Jagdzeitung 170(7): 122-128.

Tüxen R (1956) Die heutige potentielle natürliche Vegetation als Gegenstand der Vegetationskartierung. Angewandte Pflanzensoziologie 13: 5-42.

Van Wagner CE (1982) Practical aspects of the line intersect method. Canadian Forestry Service, Information Report PI-X-12.

Warren WG, Olsen PF (1964) A line intersect technique for assessing logging waste. Forest Science 10: 267-276. 
